Doi: https://doi.org/10.31578/jebs.v6i2.230

\title{
Flute Education in Turkey in the Process of COVID-19 Pandemic
}

Ajda Şenol Sakin*

\begin{abstract}
The experience of the COVID-19 pandemic worldwide has caused education to be carried out through distance learning. Due to this situation, flute instructors faced many difficulties in instrument training, which had to be done remotely in professional music education institutions. A research was conducted to determine the training and examination processes of the instructors for flute education, their experiences, readiness for online education, negativities, and solutions during the pandemic process. Convergent parallel design, one of the mixed research methods, was used in the study. The study group consists of 22 flute instructors who work in different professional music education institutions in Turkey. An open- and close-ended questionnaire was used as a data collection tool. It was revealed that flute instructors conducted classes in different ways during the pandemic, they had to make their evaluations mostly individually, and they had many difficulties due to the internet and the applications used. As a result of the research in order for online flute training to be more effective, it was recommended that both instructor communication be more active and trainers receive training that will contribute to their professional development in online education.
\end{abstract}

Keywords: Flute training, Turkey, COVID-19, pandemic, online education

\section{Introduction}

Instrument education is one of the important sub-steps of music education and its sub-branch is flute education. The aim of flute education is that the student can learn and develop flute playing, use the flute effectively, plan the study process and increase their musical skills. The realization of these goals depends on the communication and interaction between the instructor and the student. In flute education, this communication and interaction are mostly provided through face-to-face classes. In addition to verbal communication with the student, especially at the beginner level, physical interaction is also required. Control of posture, embouchure, shape, and angle of flute holding, diaphragm studies require both sampling and physical contact. On the other hand, tone development, clarity of tongue techniques, rhythmic clarity, and musical development can be improved much better with the immediate intervention of the instructor. Again, to generalize, flute classes were a process that was carried out individually by the instructors, in which the instructor listened to the work of their students and was able to provide instant feedback and correct mistakes and carry out musicality studies by exemplifying them.

With the onset of the COVID-19 epidemic, face-to-face flute training has been transformed into distance / online education. The new coronavirus disease was identified in January 2020 and started to be called COVID-19. A pandemic was declared by the World Health Organization (WHO) in March 2020, when the virus affected the world in a short period of three months (WHO, 2020; Budak \& Korkmaz, 2020). Following the COVID-19 pandemic, different measures have been taken all over

\footnotetext{
* Music Education Department, Faculty of Education, Bursa Uludag University, Turkey.

Corresponding Email: ajdasenol@uludag.edu.tr
} 
the world. The most important of these are travel restrictions, curfews, cancellation of activities to be held, the closing of businesses, and the declaration of a state of emergency (Budak \& Korkmaz, 2020).

In addition to all these measures, changes have been made in education styles, although they differ from country to country. Online/distance education has been introduced at many levels. With the measures taken afterward, training processes continued online, in a hybrid (online + face-to-face), and face-to-face regime. In these processes, it was thought that conducting the singing and wind instrument classes of music education could be a high-risk activity. With this in mind, each institution carried out these trainings in line with its own decisions and measures.

According to the research carried out by the National Association for Music Education (NAfME) within the United States of America, singing and instrument training in schools differs from one state to another. While there is no specific explanation for this area in the guides of many states such as Arizona, Arkansas, Colorado, etc., they have explained the measures in detail that can and should be taken for these trainings. Among the measures to be taken, it is recommended to make rehearsals in open areas as much as possible, to ventilate the halls to be used, the necessity to wear masks, to pay attention to the distance, to use barriers that cannot be worn, and to hold virtual music classes to minimize the risk of viral contamination. While there are states that only allowed these trainings in the open air, there are also states that did not allow these trainings on the grounds that "activities where sounds are projected, such as choir, theater, or band, increase the risk of respiratory droplets spreading even at a physical distance of about 2 meters. Even if the group size and the distance of 2 meters can be maintained, such activities should be canceled" (NAfME, 2021).

The first cases in Turkey of COVID-19 were announced on March 112020 by the Ministry of Health (Republic of Turkey Ministry of Health, 2021). After this announcement, education was stopped immediately, and the necessary planning was made to start distance education. This process was planned by the Ministry of National Education for vocational institutions that carry out flute education, and by university rectors for universities. In addition, each instructor tried to continue their flute classes most effectively, taking into account both their own and the students' situations.

Flute classes, which had been mostly conducted face-to-face, were suddenly interrupted by the COVID-19 pandemic and the search for new methods to conduct these classes forced flute instructors to teach online. However, this training method was normally not used by many trainers, and it is a method that they consider with prejudice and declared as unusable in instrument training. Nevertheless, the use of online and distance education models has become a necessity in today's education system. In particular, the sound, instrument, and rhythm elements, which are the most important elements of instrument training, as well as the need for contact with students at the beginner level and immediate feedback require face-to-face training, but the decisions were taken and the health that needs to be protected made online education compulsory. Although the instructors made significant efforts to achieve the targeted gains for their students in this process, it is thought that they had to conduct different from usual activities, and they faced many difficulties due to it.

This research was conducted to determine the training and exam processes of the instructors for flute education, their experiences, their readiness for online education, their negativities, and their solutions during the COVID-19 pandemic process. For this purpose, the research problem statement determined as "How can flute education in Turkey process of COVID-19 pandemic be organized?" The research seeks answers to the following questions for the solution of this general problem.

1- How did the flute instructors conduct their classes and exams during the pandemic process?

2- What were the difficulties experienced by flute instructors during the pandemic process? How did they overcome these difficulties? 
3- Could the lesson/class goals be achieved during the pandemic process?

4- Do the instructors find themselves competent in teaching online?

5- What are the positive experiences of flute instructors during the pandemic process?

6- What are the suggestions of flute instructors regarding the effective implementation of the flute classes and the programs, applications, etc. that can be used during the classes during the pandemic process?

\section{Literature review}

The changes, difficulties, and experiences in musical education and instrument training during the COVID-19 pandemic process were investigated in the article in terms of both instructors and students, and it was tried to contribute to the understanding and improvement of this process.

De Bruin (2021) investigated the teaching practices of instrument educators in the COVID-19 environment in terms of relationality. In this context, he had interviews with the instructors over Zoom. Three themes were revealed as a result of the interviews. These are: teacher-student cohesion, dialogic communication skills, and student connections. Thus, the relationship between the teacher and his/her students in this process was determined in detail.

Aksoy, Güçlü, and Nayir (2020) examined the educational processes of music courses during the pandemic process. Accordingly, while the music courses had the opportunity to learn more about distance education models in this process, they preferred the synchronous model, which mostly includes the video conferencing method.

He (2020) introduces the versatile and multi-purpose features of online music teaching from the perspective of modern teaching theory and learning theory and gives the mode of implementation. He also provides an example of a performancebased online music class to help music teachers design and develop their classes in the COVID-19 process.

Barate, Haus, and Ludovico (2020) focused on the applicability of IEEE 1599 to music education and its usability in the COVID-19 pandemic process, while providing detailed information about IEEE 1599, an international standard that aims to define music and music-related information with a multi-layered approach.

Akyürek (2020) determined the opinions of the teaching staff about to the distance music education process in his article. According to that research, it was concluded that academic staff working in music programs of universities were caught unprepared for online education, and that apart from a few instructors, the majority of music educators did not have the knowledge, experience, acquisition and preparation for distance education.

Hash (2020) examines the practices, experiences and perspectives of school band and music ensemples directors who had to use distance learning models in the spring 2020 period due to the COVID-19 outbreak. According to Hash, teachers working in schools with a high poverty level and in rural areas had more difficulty than teachers working in schools with a low poverty level. In addition, the process of distance learning has some positive aspects. For instance, teachers were able to include materials prepared in line with a wider range of technologies in their classes, focus more on individual musicianship, and support student creativity through composition and arrangements. 
In his article, Nichols (2020) touched on the issues of access to learning and e quality in music education during and after the pandemic and stated that many students encountered inequalities in education during this period. He also says that these problems must be overcome with the right efforts of governments and teachers.

Sakarya and Zahal (2020) determined student views on distance violin education during the pandemic process with their research. According to the research, most of the students advocate that violin training should be done face-to-face. In addition, it is recommended that studies to shape the distance education approach in music education in obligatory situations should be carried out rather according to the blended education model than based on fully synchronous and asynchronous classes.

Özer and Üstün (2020) in their article have identified Haci Bektas Veli Nevsehir University in Turkey students' of music education department views on education in the process they perform in the COVID-19 pandemic. In the study, it was concluded that the students of the music department did not find web-based distance education as efficient as face-to-face education, especially in applied courses, and there were connection and technical problems experienced by the students during the course.

Johnson and Merrick (2020) determined that in the COVID-19 process, regular online synchronized meetings with teachers produces certain positive effects on students to support their well-being.

In their research, Umuzdaş and Baş (2020) determined the perceptions and experiences of conservatoire students regarding distance education during the COVID-19 outbreak. It was determined that there was a performance loss in applied areas in the distance education process in general, on the other hand, it was seen that students gain skills such as research, time management and self-regulation with this education model.

In their research, Bolat and Akıncı determined the status, attitudes and possibilities of music instructors (Bolat \& Akinci, 2020a) and music students (Bolat \& Akinci, 2020b) during the COVID-19 pandemic process and what they were interested in during this process.

\section{Methodology}

\subsection{Methods}

Convergent parallel pattern, one of the mixed research methods, was used in the study. In this design, qualitative and quantitative data are collected and analyzed simultaneously during the research process, and then the two result sets are combined into a single comment (Creswell \& Plano Clark, 2020, p. 85). There are three basic forms of the convergent pattern. In the research, data validation form of these forms was used. In this form, a questionnaire or interview form includes both open-ended and closedended questions, and the results of open-ended questions are used to verify the results of closed-ended questions (Creswell $\&$ Plano Clark, 2020: 90).

Accordingly, in the study, it was tried to determine how the flute instructors carried out their flute training during the COVID-19 process, the negativities experienced in this process and their opinions about online flute training through both closedended and open-ended questions through interviews made based on their experiences.

\subsection{Participants}

The purposive sampling method, one of the qualitative research methods, was used in the sample selection of the study. "The purposeful sampling consists of people who are experienced and consciously selected about the basic phenomenon or key concept that the researchers examine in their studies" (Creswell \& Plano Clark, 2020, p. 187-188). In a homogeneous sampling for 
this research, this method was used by the researcher to solve the research problem. The population of the research involved professional flute educators working in the field of music education in Turkey. In this context, the researcher tried to reach 32 flute instructors working in fine arts high schools ${ }^{1}$, departments of musical education, conservatoires, and music departments of the faculty of fine arts. Also, the teachers working in the fine arts high school were requested to send the questionnaire to their colleagues. As a result of all these efforts, 22 instructors answered the interview questions.

Accordingly, the study group of the study involved flute instructors working in different institutions who accepted to participate in the study on a voluntary basis. The names of the instructors are not included in the study, they are coded as Participant 1 (P1), Participant 2 (P2), etc. The demographic information concerning the participants is presented in Table 1.

Table 1. Demographic information concerning the participants

\begin{tabular}{lcr}
\hline & $\mathbf{n}$ & $\%$ \\
\hline Institution Type & 7 & 31.82 \\
Fine Arts High School (FAHS) & 7 & 31.82 \\
Music Education Department & 5 & 22.73 \\
Conservatoire & 3 & 13.63 \\
Fine Arts Faculty Music Department & 3
\end{tabular}

\begin{tabular}{|c|c|c|c|}
\hline & Institution Name & & \\
\hline & Nevit Kodallı FAHS & 1 & 4.5 \\
\hline & Diyarbatır FAHS & 1 & 4.5 \\
\hline & Başakşehir İstanbul Technical University İsmail Dede Efendi & 1 & 4.5 \\
\hline FAHS & & & \\
\hline & Tek FAHS & 1 & 4.5 \\
\hline & Aşık Veysel FAHS & 1 & 4.5 \\
\hline & Balıkesir University & 1 & 4.5 \\
\hline & Zeki Müren FAHS & 2 & 9 \\
\hline & Çanakkale On Sekiz Mart University & 1 & 4.5 \\
\hline & Dokuz Eylül University & 1 & 4.5 \\
\hline & Trakya University & 1 & 4.5 \\
\hline & Marmara University & 1 & 4.5 \\
\hline
\end{tabular}

\footnotetext{
${ }^{1}$ Fine arts high schools in Turkey is the general name for the high school level in music and art education. Similarly, educational institutions that include different branches of art (music, art, etc.) are generally referred to as fine arts departments.
} 


\begin{tabular}{|c|c|c|}
\hline Muğla Sıtkı Koçman University & 1 & 4.5 \\
\hline 19 Mayıs University & 1 & 4.5 \\
\hline Bursa Uludağ University & 2 & 9 \\
\hline Mimar Sinan Güzel Sanatlar University & 1 & 4.5 \\
\hline Trabzon University & 1 & 4.5 \\
\hline Adnan Menderes University & 1 & 4.5 \\
\hline Giresun University & 1 & 4.5 \\
\hline Akdeniz University & 2 & 9 \\
\hline \multicolumn{3}{|l|}{ Title } \\
\hline Teacher & 7 & 31.82 \\
\hline Research Assistant & 1 & 4.5 \\
\hline Lecturer & 1 & 4.5 \\
\hline Lecturer Doctor & 1 & 4.5 \\
\hline Assistant Professor & 3 & 13.63 \\
\hline Associate Professor & 7 & 31.82 \\
\hline Professor & 2 & 9 \\
\hline
\end{tabular}

\section{Experience as a flute instructor / years}

\begin{tabular}{lcc}
$1-4$ & 1 & 4.5 \\
$5-9$ & 4 & 18 \\
$10-14$ & 4 & 18 \\
$15-19$ & 7 & 31.82 \\
20 and above & 6 & 27.28 \\
\hline
\end{tabular}

\section{Having the technical equipment to teach online}

\begin{tabular}{ccc} 
Yes & 21 & 95.5 \\
No & 1 & 4.5 \\
\hline Total & 22 & 100 \\
\hline
\end{tabular}

When Table 1 is examined, it is seen that 7 of the flute instructors who participated in the study were working in fine arts high schools, 7 in music education departments, 5 in conservatoirs, and 3 in the music departments of the faculty of fine arts.Seven of them were teachers, seven - associate professors, three - assistant professors, two - professors, one - a lecturer doctor, one - a 
lecturer and one is a research assistant. Seven of them had between 15-19 years, six - 20 years and over, four - between 5-9 years, four - were between 10-14 years and one had 1-4 years of experience as a flute instructor. Totally they worked for 19 different institutions in Turkey.

\subsection{Instrumentation}

A questionnaire consisting of open-ended and multiple-choice questions was used as a data collection tool in the study. The questionnaire included open-ended and closed-ended questions that allowed the researcher to investigate the relevant subject in depth by conducting a literature review. The designed by the researcher form was sent to two experts in the field of flute education and its final version was formed by taking their opinions into consideration. The interview form was transferred to the online environment via Google Forms to reach more flute instructors and sent to the study group via Whatsapp, Instagram, Facebook, and e-mail.

The first part of the questionnaire consisted of questions about the demographic information concerning the study group. Questions were asked about how the flute training and exams were carried out at the beginning of the pandemic process and in the following period, the difficulties experienced in these periods, how to overcome the difficulties, and the situations in which the flute instructors found themselves competent.

\subsection{Data analysis}

There are many methods such as making direct quotations from the interview, reporting information with quantitative and qualitative methods, content and descriptive analysis in order to include questionnaire results in the research (Büyüköztürk et al., 2014 , p. 168). In addition to analyzing the data obtained from the research with content and descriptive analysis methods, closedended questions were analyzed in terms of frequency and percentage by quantitative data analysis methods. The quantitative data in the study provided findings to support the qualitative data. In the research, themes and codes were developed from the data obtained from open-ended questions.

According to Başkale (2016), it is more correct to use terms such as credibility, the accuracy of results, researcher's competence, reliability, confirmability, and transferability in qualitative research instead of terms of validity and reliability. In this study, the credibility step with participant confirmation and expert review (peer evaluation); transferability step with purposeful sampling and detailed description of the participants; With the detailed description of the literature, research methods, and the examination of the results of other researchers, the reliability step was tried to reduce the bias of the researchers and to provide the confirmability step by direct quotations from the answers.

\section{Findings and Results}

Since flute instructors might have conducted online classes in this process before the findings about the flute classes they conducted during the COVID-19 process, it was asked whether the instructors had such an experience before the pandemic. The findings obtained from the participants on this subject are shown in Table 2.

Table 2. Findings of the participans' online lecturing experience before the COVID-19 outbreak

\begin{tabular}{lcl}
\hline Theme & Sample expressions \\
\hline Yes & 4 & $\begin{array}{l}\text { In 2002, we had to leave because of my appointment with a student whom I taught face-to- } \\
\text { face. In order to continue the classes, I think we worked on MSN for a while using web cam } \\
\text { and microphone under the conditions of that period. Although we experienced visual }\end{array}$ \\
\hline
\end{tabular}


impairment due to the internet quality during the working process, we did not experience disconnection, freezing and sound problems as we do now (P8).

I delivered trainings on flipped learning. Especially the online delivery of theoretical subjects before face-to-face training and using more advanced applications provided an advantage. It became a model loved by students as well (P18)

I was conducting classes on Skype and WhatsApp (P1).

No $18 \quad$ No, there was not (P19).

When the data obtained were examined, it was determined that four of the instructors who were in the study group had online lecturing experience before the COVID-19 process. In addition to the instructors who teach through different practices, there was also a flute instructor who applied the flipped learning education model, one of the distance education methods, in his/her work. Apart from this, 18 instructors stated that they had no previous experience in this field.

\subsection{Class Processing and Assessment Methods of Flute Instructors in the COVID-19 Pandemic}

Flute instructors were asked how they conducted their flute classes at the beginning of the COVID-19 epidemic (March - June, spring semester of 2020/2019-2020 education year). The responses of the participants are included in Table 3 .

Table 3. How the participants carried out flute classes at the beginning of the COVID-19 epidemic

\section{Class processing method}

Online synchronization (video lecture via an application such as Eba, whatsapp, zoom, Google meet etc.)

Online asynchronous (student sent video or audio recording, I gave written feedback)

Online asynchronous (lecture grade sharing via school / university automation system)

Hybrid - face-to-face + online (mostly online, but sometimes I supplemented it with face-to-face classes)

I prepared videos containing technical studies on the weekly content of the course and uploaded them to the system

When Table 3 is examined, it is seen that flute instructors conducted their flute classes in different ways at the beginning of the COVID 19 pandemic. In this process, the participants held online synchronous classes intensively. In addition, it was determined that they conducted their classes with asynchronous applications and lecture-note sharing. While one of the participants continued to teach face-to-face, one participant stated that he supported his students with videos containing technical studies as well as synchronous lectures.

Flute instructors were asked about how they conducted their 2020-2021 fall semester flute classes. The responses of the participants are included in Table 4. 
Table 4. How the participants carried out flute classes at the 2020-2021 fall semester

\begin{tabular}{lc}
\hline Class processing method & $\mathbf{n}$ \\
\hline Face-to-face & 2 \\
Online synchronization (video lecture via an application such as Eba, whatsapp, zoom, Google meet etc.) & 16 \\
Online asynchronous (student sent video or audio recording, I gave written feedback) & 2 \\
Hybrid - face-to-face + online (mostly online but sometimes I supplemented with face-to-face classes) & 6 \\
\hline
\end{tabular}

When Table 4 is examined, it is seen that in the course of the 2020-2021 fall semester, flute instructors continued to conduct their classes synchronously online, as well as two participants taught face-to-face and two participants conducted their classes asynchronously. In addition to these, six participants stated that they supplemented their online flute classes via face-to-face classes.

Flute instructors were asked about how they conducted their exams at the end of the spring semester of 2019-2020 education year. The answers given by the participants are shown in Table 5 .

Table 5. Views on the 2019-2020 spring semester exam evaluation

\begin{tabular}{|c|c|c|c|c|}
\hline Theme & Sub theme & Codes & $\mathbf{n}$ & Sample expressions \\
\hline \multirow{8}{*}{ 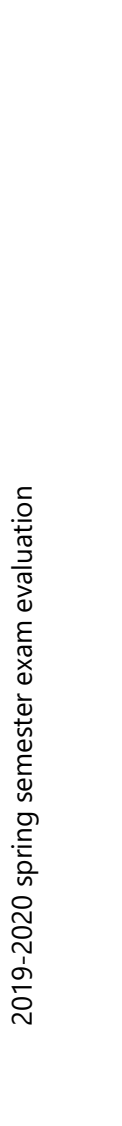 } & \multirow{5}{*}{ Individual } & \multirow{2}{*}{ Face-to-face } & \multirow{2}{*}{3} & $\begin{array}{l}\text { I made an individual assessment face-to- } \\
\text { face }(\mathrm{P} 3)\end{array}$ \\
\hline & & & & $\begin{array}{l}\text { I made a face-to-face assessment before } \\
\text { the pandemic (P4). }\end{array}$ \\
\hline & & $\begin{array}{l}\text { Online } \\
\text { (asynchronous) }\end{array}$ & 11 & $\begin{array}{l}\text { The students sent the video / audio } \\
\text { recordings of the scales, etudes and pieces } \\
\text { they worked on and I evaluated it on } \\
\text { individual basis ( }(2) \text {. }\end{array}$ \\
\hline & & $\begin{array}{l}\text { Performance } \\
\text { written }\end{array}$ & 3 & $\begin{array}{l}\text { I applied a performance evaluation } \\
\text { besides the written exam ( } P 5) \text {. }\end{array}$ \\
\hline & & $\begin{array}{l}\text { Classroom } \\
\text { performance grade }\end{array}$ & 1 & $\begin{array}{l}\text { I gave a classroom performance grade } \\
\text { (P10). }\end{array}$ \\
\hline & Commission & $\begin{array}{l}\text { Online } \\
\text { (asynchronous) }\end{array}$ & 1 & $\begin{array}{l}\text { The students sent the video / audio } \\
\text { recordings of the scales, etudes and pieces } \\
\text { they worked on, and we considered it as a } \\
\text { commission (P20). }\end{array}$ \\
\hline & & $\begin{array}{l}\text { Online } \\
\text { (synchronization) }\end{array}$ & 1 & $\begin{array}{l}\text { Online live commission exam was held } \\
\text { (P12). }\end{array}$ \\
\hline & No exam & & 4 & $\begin{array}{l}\text { There was no exam and no grades were } \\
\text { given. In line with the ministry's decisions, } \\
\text { students passed to the next class without } \\
\text { examination (P9). }\end{array}$ \\
\hline
\end{tabular}


When Table 5 is examined, it is seen that flute instructors held different examinations and evaluations at the end of the spring term of 2019-2020 education year after the COVID-19 epidemic started. The most common form of these exams was the individual assessment of students by 11 participants, by audio recording or by sending video. In addition, when the data were examined in more detail, it was determined that the flute teachers working in the Fine Arts High Schools affiliated to the Ministry of National Education cancelled the examinations in line with the ministry's decision, one out of three teachers evaluated the video/audio recording of their students individually, one teacher conducted a face-to-face evaluation, and the other carried out the assessment before the pandemic. Two flute instructors stated that they applied a commission assessment in this process, which is normally held as an individual assessment. One of them stated that they held an asynchronous evaluation through recording listening, while the other stated that $s /$ he made an evaluation with an "online live (synchronous)" connection. In addition to performance evaluation, there were three instructors who held a written exam.

Flute instructors were asked about how they conducted their exams at the end of the 2020-2021 fall semester (when the COVID19 pandemic process progressed). The answers given by the participants can be seen in Table 6 .

Table 6. Views on the 2020-2021 fall semester exam evaluation

\begin{tabular}{|c|c|c|c|c|}
\hline Theme & Sub theme & Codes & $\mathbf{N}$ & Sample expressions \\
\hline \multirow{8}{*}{ 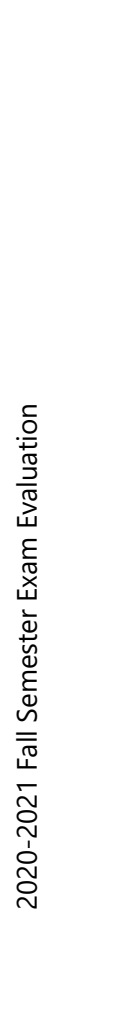 } & \multirow{4}{*}{ Individual } & Face-to-face & 3 & $\begin{array}{l}\text { I held an individual assessment face-to-face } \\
\text { (P1) }\end{array}$ \\
\hline & & $\begin{array}{l}\text { Online } \\
\text { (asynchronous) }\end{array}$ & 10 & $\begin{array}{l}\text { The students sent the video / audio } \\
\text { recordings of the scales, etudes and pieces } \\
\text { they worked on and I evaluated them } \\
\text { individually (P2). }\end{array}$ \\
\hline & & $\begin{array}{l}\text { Performance+ } \\
\text { written }\end{array}$ & 1 & $\begin{array}{l}\text { I conducted a performance evaluation } \\
\text { besides the written exam (P5). }\end{array}$ \\
\hline & & $\begin{array}{l}\text { Online } \\
\text { (synchronization) }\end{array}$ & 1 & $\begin{array}{l}\text { I held an online exam evaluation individually } \\
\text { (P6). }\end{array}$ \\
\hline & \multirow{2}{*}{ Commission } & $\begin{array}{l}\text { Online } \\
\text { (asynchronous) }\end{array}$ & 5 & $\begin{array}{l}\text { The students sent the video / audio } \\
\text { recordings of the scales, etudes and pieces } \\
\text { they worked on, and we considered it as a } \\
\text { commission ( }(20) \text {. }\end{array}$ \\
\hline & & $\begin{array}{l}\text { Online } \\
\text { (synchronization) }\end{array}$ & 1 & Online live commission exam was held (P12). \\
\hline & No exam & & 1 & $\begin{array}{l}\text { We did not conduct any exams, I only gave a } \\
\text { performance grade (P5). }\end{array}$ \\
\hline & Record & & 1 & Record (P16). \\
\hline
\end{tabular}

When Table 6 is examined, it is seen that most of the instructors who were in the study group, individually make an online asynchronous evaluation, and this evaluation is done by assessing the students' recording of the scales, etudes, and pieces they study on sent to the instructor. In addition, three instructors stated that they held individual face-to-face evaluations, one instructor conducted a written exam in addition to the performance exam, and one instructor stated that $\mathrm{s} / \mathrm{he}$ held an online (synchronization) exam evaluation individually. In addition to individual evaluations, it is seen that the 2020-2021 fall semester final exams were also evaluated by the commission. Five instructors stated that the audio or video recordings sent by the students 
were evaluated by a commission, and one instructor stated that they applied an online live commission evaluation. Besides, there was also an instructor who dis not hold an exam but only gave a performance score only according the recordings. Whether the recordings were evaluated individually or by a commission was not specified by the instructor

\subsection{Difficulties and Solutions of Flute Instructors in the COVID-19 Process}

Flute instructors were asked about the difficulties they faced during the beginning of the pandemic process. The themes, subthemes, codes, and sample expressions created in line with the responses of the instructors are included in Table 7.

Table 7. Difficulties experienced by participants during the pandemic process

\begin{tabular}{|c|c|c|c|c|}
\hline Theme & Sub theme & Codes & $\mathbf{n}$ & Sample expressions \\
\hline & \multirow{8}{*}{$\begin{array}{l}\text { Course } \\
\text { Process }\end{array}$} & $\begin{array}{l}\text { Asynchronous } \\
\text { classes }\end{array}$ & 2 & $\begin{array}{l}\text { Since the classes were conducted asynchronously, it was } \\
\text { impossible to intervene in students' basic technical } \\
\text { problems immediately. Unfortunately, as it took time to } \\
\text { provide feedback about any technical deficiencies or } \\
\text { students' errors, some mistakes were fossilized (P13). }\end{array}$ \\
\hline & & \multirow[b]{2}{*}{ Posture control } & \multirow[b]{2}{*}{2} & Posture control was not possible (P12). \\
\hline & & & & $\begin{array}{l}\text { Not being able to intervene in posture, holding and } \\
\text { position changes during online training. I had trouble } \\
\text { describing some possible situations because touching the } \\
\text { student / instrument was eliminated. }\end{array}$ \\
\hline & & $\begin{array}{l}\text { Musicality / } \\
\text { technical studies }\end{array}$ & 1 & $\begin{array}{l}\text { It is very difficult to do musical and technical studies } \\
\text { (P12). }\end{array}$ \\
\hline & & \multirow[b]{2}{*}{ Playing together } & \multirow[b]{2}{*}{2} & No option to teach by playing together (P14). \\
\hline & & & & $\begin{array}{l}\text { Delay in duet and accompaniment pieces due to } \\
\text { synchronous regime challenges ( } P 21) \text {. }\end{array}$ \\
\hline & & \multirow[b]{2}{*}{ Other } & \multirow[b]{2}{*}{2} & $\begin{array}{l}\text { To ensure that students can understand the issues they } \\
\text { have difficulties understanding (P4) }\end{array}$ \\
\hline & & & & $\begin{array}{l}\text { Finding solutions to the problems of students who cannot } \\
\text { adapt to online education or cannot attend classes due to } \\
\text { technical inadequacies (P11). }\end{array}$ \\
\hline & \multirow{4}{*}{$\begin{array}{l}\text { Technical } \\
\text { issues }\end{array}$} & $\begin{array}{l}\text { Lack } \\
\text { institutional } \\
\text { licensed } \\
\text { programs }\end{array}$ & 1 & $\begin{array}{l}\text { Since there was no online program purchased by the } \\
\text { university at that time, I worked on zoom with my own } \\
\text { means. However, some students were concerned about the } \\
\text { security of the program (P6). }\end{array}$ \\
\hline \multirow{3}{*}{ 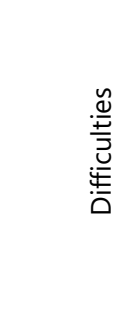 } & & \multirow[b]{2}{*}{$\begin{array}{l}\text { Insufficiency } \\
\text { computer } \\
\text { hardware }\end{array}$} & \multirow[b]{2}{*}{2} & Students' device inadequacies (P1). \\
\hline & & & & $\begin{array}{l}\text { Our school computers were not enough in terms of } \\
\text { hardware. We couldn't conduct the classes from school } \\
\text { (P8). }\end{array}$ \\
\hline & & quality & 1 & Sound does not reach in good quality (P12) \\
\hline
\end{tabular}




\begin{tabular}{ll}
\hline $\begin{array}{l}\text { Digital media } \\
\text { fatigue }\end{array}$ & $\begin{array}{l}\text { Listening to videos is more tiring than listening to live } \\
\text { performance. In addition, the digital environment was } \\
\text { tiring the eyes (P17). }\end{array}$ \\
\hline & Internet problems (P1) \\
\hline $\begin{array}{l}\text { Slow internet (P9) } \\
\text { technological / } 8 \\
\text { Internet problems }\end{array}$ & $\begin{array}{l}\text { I had a lot of problems connecting to the internet and } \\
\text { working synchronously (P10). }\end{array}$ \\
\hline
\end{tabular}

Synchronous regime and connection problem (P22).

\begin{tabular}{|c|c|c|c|}
\hline \multirow{9}{*}{$\begin{array}{l}\text { Problems } \\
\text { caused by } \\
\text { students }\end{array}$} & \multirow{2}{*}{$\begin{array}{l}\text { Instrument / } \\
\text { score deficiency }\end{array}$} & \multirow{2}{*}{2} & $\begin{array}{l}\text { Some students are not with their instruments because } \\
\text { they went to their hometown unprepared (P6). }\end{array}$ \\
\hline & & & Sometimes there were scores missing (K5) \\
\hline & \multirow{3}{*}{$\begin{array}{l}\text { Student } \\
\text { absenteeism }\end{array}$} & \multirow{3}{*}{3} & $\begin{array}{l}\text { Student participation decreased significantly towards the } \\
\text { end of the term. The statement of the Ministry of National } \\
\text { Education that "you are only responsible for the 1st term } \\
\text { subjects" caused students to vacate the classes (P3). }\end{array}$ \\
\hline & & & Absenteeism of students (P9). \\
\hline & & & Less attendance (P22) \\
\hline & \multirow{3}{*}{$\begin{array}{l}\text { New start in } \\
\text { instrument } \\
\text { training }\end{array}$} & \multirow{3}{*}{3} & $\begin{array}{l}\text { Since the 9th grade students will start their instrument } \\
\text { training for the first time, this process was not efficient }(\mathrm{P} 2)\end{array}$ \\
\hline & & & $\begin{array}{l}\text { To be able to set the posture, hold and embouchure of the } \\
\text { beginner students ( } \mathrm{P} 20) \text {. }\end{array}$ \\
\hline & & & Tone and intonation development of new students (P21). \\
\hline & Motivation & 1 & Providing student motivation (P18). \\
\hline \multirow{3}{*}{$\begin{array}{l}\text { Instructor- } \\
\text { related } \\
\text { issues }\end{array}$} & $\begin{array}{l}\text { Technological } \\
\text { insufficiency }\end{array}$ & 1 & $\begin{array}{l}\text { We didn't know how to use Microsoft Teams. The } \\
\text { university did not find it appropriate to use Zoom program } \\
\text { due to security vulnerabilities. We had a little difficulty in } \\
\text { adapting to the program (P8). }\end{array}$ \\
\hline & \multirow{2}{*}{ Environment } & \multirow{2}{*}{2} & Studying online, not at school (P2) \\
\hline & & & Working at home was a bit difficult (P5). \\
\hline
\end{tabular}

When Table 7 is examined, it is seen that flute instructors experienced many difficulties in the spring semester of 2019-2020, when the COVID-19 pandemic just started, including the course process, technical issues, student-induced problems, and instructorrelated problems. Flute instructors had a lot of trouble in terms of the internet. The internet connection and sync problems, and the audio quality problems they experienced as a result of this, are technical problems, but they made the online lecturing process difficult for the instructors. In addition, the instructors also had difficulties in students' absenteeism, motivation, and lack of instruments. The problems faced by the lecturers during the class can be summarized as asynchronous classes, not being able to interfere with posture and holding, difficulties in musical and technical study, and togetherness (play together). Also, the 
instructors had difficulties in explaining the incomprehensible issues and finding solutions to the problems of the students who had adaptation problems.

In this process, the flute instructors were asked how they came to solutions of the difficulties and problems they faced. Table 8 was created in line with the data obtained from the participants.

Table 8. Participants' views on solutions

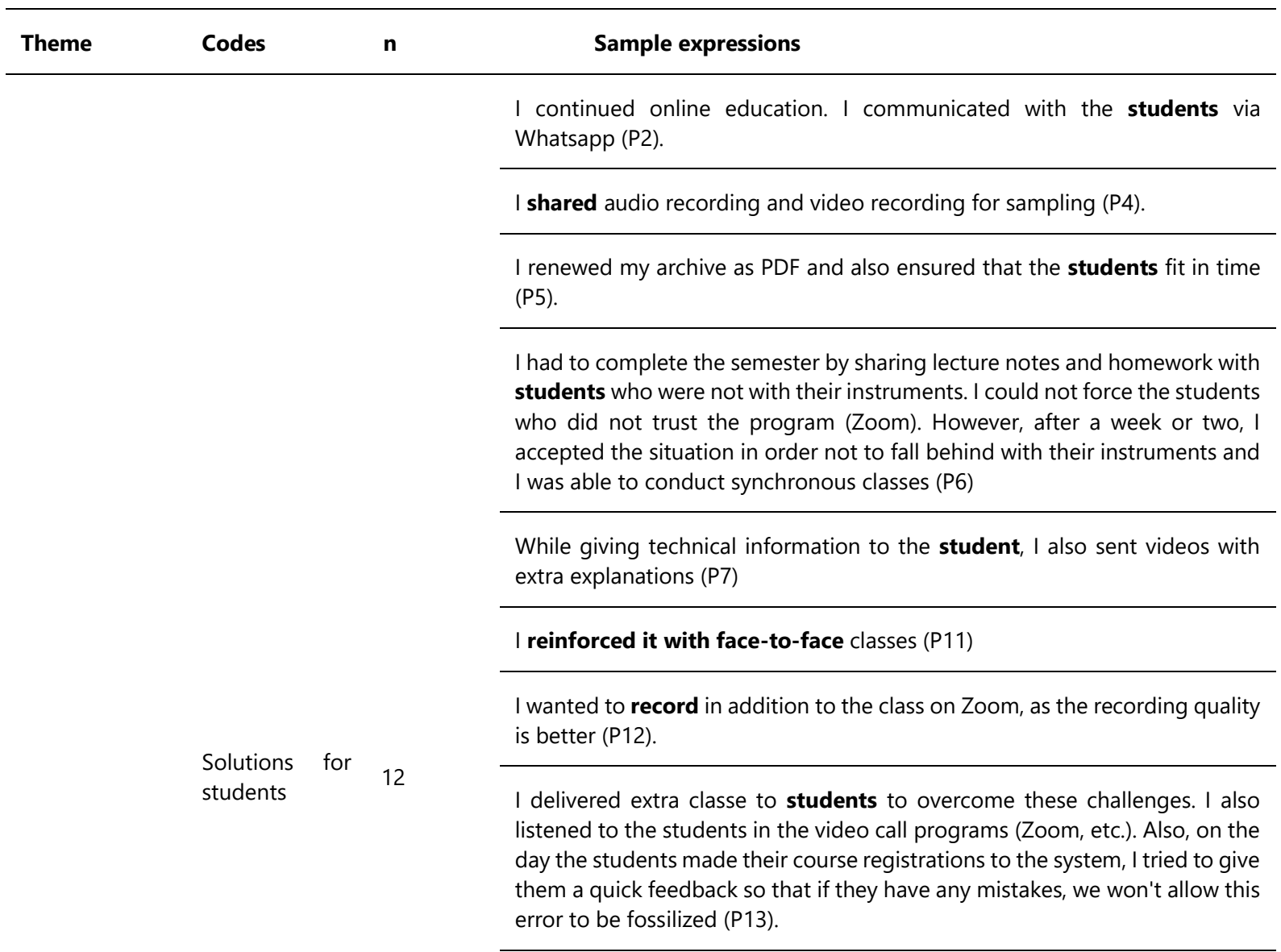

Our system was not suitable for synchronous education, so I told my students that this process was temporary as much as possible, and I suggested the importance of regular study (P18).

I tried to convey all these techniques myself in online classes in the best way possible (P20).

I shared the recordings I made with the metronome for the duets with my students. Due to the lack of control in face-to-face education, I preferred studies and pieces that would not technically force them in terms of preventing finger technique, posture and holding position disorders of my beginner students. I focused more on fast score reading and scale information than artistim and musicality (P21).

By making and having video recordings outside of the classroom, as the sound quality can be low in live classes (P22). 


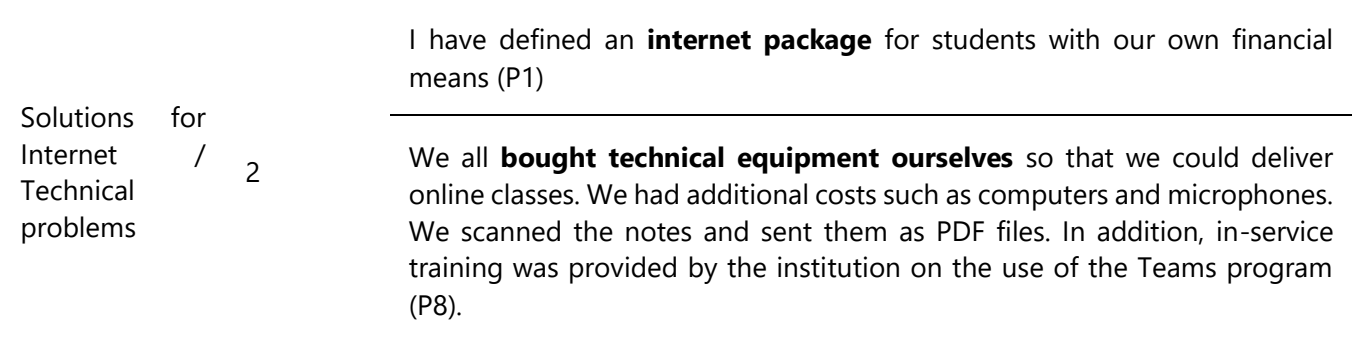

With only one of my four students, distance education continued smoothly and efficiently (P3)

\begin{tabular}{|c|c|c|}
\hline $\begin{array}{l}\text { Problems are } \\
\text { not resolved }\end{array}$ & 6 & $\begin{array}{l}\text { We had to use the "Sakai" application to get additional tuition fees. However, } \\
\text { since the system infrastructure was insufficient, I had to teach from other } \\
\text { channels like Whatsapp. I did not get any additional tuition fees (P10). }\end{array}$ \\
\hline
\end{tabular}

We could not overcome the problems (P15).

When Table 8 is examined, it is seen that educators produce solutions to the difficulties experienced by students or problems caused by students in different ways. In addition, it was determined that flute instructors found solutions to problems caused by the internet or technical equipment by making certain expenses. They contributed to the solution process by organizing in-service trainings for the programs recommended by academic staff in this process. On the other hand, six participants could not solve the problems they experienced regarding online education during the COVID-19 pandemic process.

Considering that some measures may have been taken in the summer period, the participants wer also asked about the difficulties experienced by the trainers in the later period of the pandemic (fall semester of 2020-2021 academic year). Most of the participants stated that internet and hardware-related problems continued, and technical and musical development could not be achieved in the classes taught in this way. In addition to this, while it was stated that the students had absenteeism, unwillingness and motivation problems, one K10 instructor said, "Since I prepared my students for the competition, online classes were not enough. That's why I taught face-to-face". Despite all these negativities, there are also flute instructors stating that the 2020-2021 fall semester has been much smoother than the spring semester of 2019-2020 and the system has been settled.

\subsection{The Situation of Flute Instructors to Achieving the Targeted Course Outcomes in the COVID-19 Process}

The answers given by the instructors regarding achieving the targeted course outcomes in flute training can be seen in Table 9 .

Table 9. The status of achieving the targeted flute course outcomes.

\begin{tabular}{lcccccccc}
\hline \multirow{2}{*}{ Semester } & \multicolumn{2}{c}{ Yes } & \multicolumn{2}{c}{ No } & \multicolumn{2}{c}{ Partially } & \multicolumn{2}{c}{ Total } \\
\cline { 2 - 9 } & $n$ & $\%$ & $n$ & $\%$ & $n$ & $\%$ & $n$ & $\%$ \\
\hline 2019-2020 spring semester & 7 & 31.8 & 3 & 13.6 & 12 & 54.5 & 22 & 100 \\
$2020-2021$ fall semester & 8 & 36.4 & 2 & 9.1 & 12 & 54.5 & 22 & 100 \\
\hline
\end{tabular}

When Table 9 is examined, it is seen that most of the flute instructors stated that they partially achieved their goals. In addition, the instructors who said 'yes' are seven people in the spring semester of 2019-2020 and eight in the next term; It was determined that the number of those who said 'no' decreased at the later stages of the pandemic process. 
The instructors were asked achievng which targeted outcomes they had difficulties in during the online education in the spring semester of 2019-2020 education year. The themes and codes created in line with the answers obtained from the interviews are shown in Table 10.

Table 10. Flute class targeted outcomes that were difficult to achieve during the COVID-19 pandemic

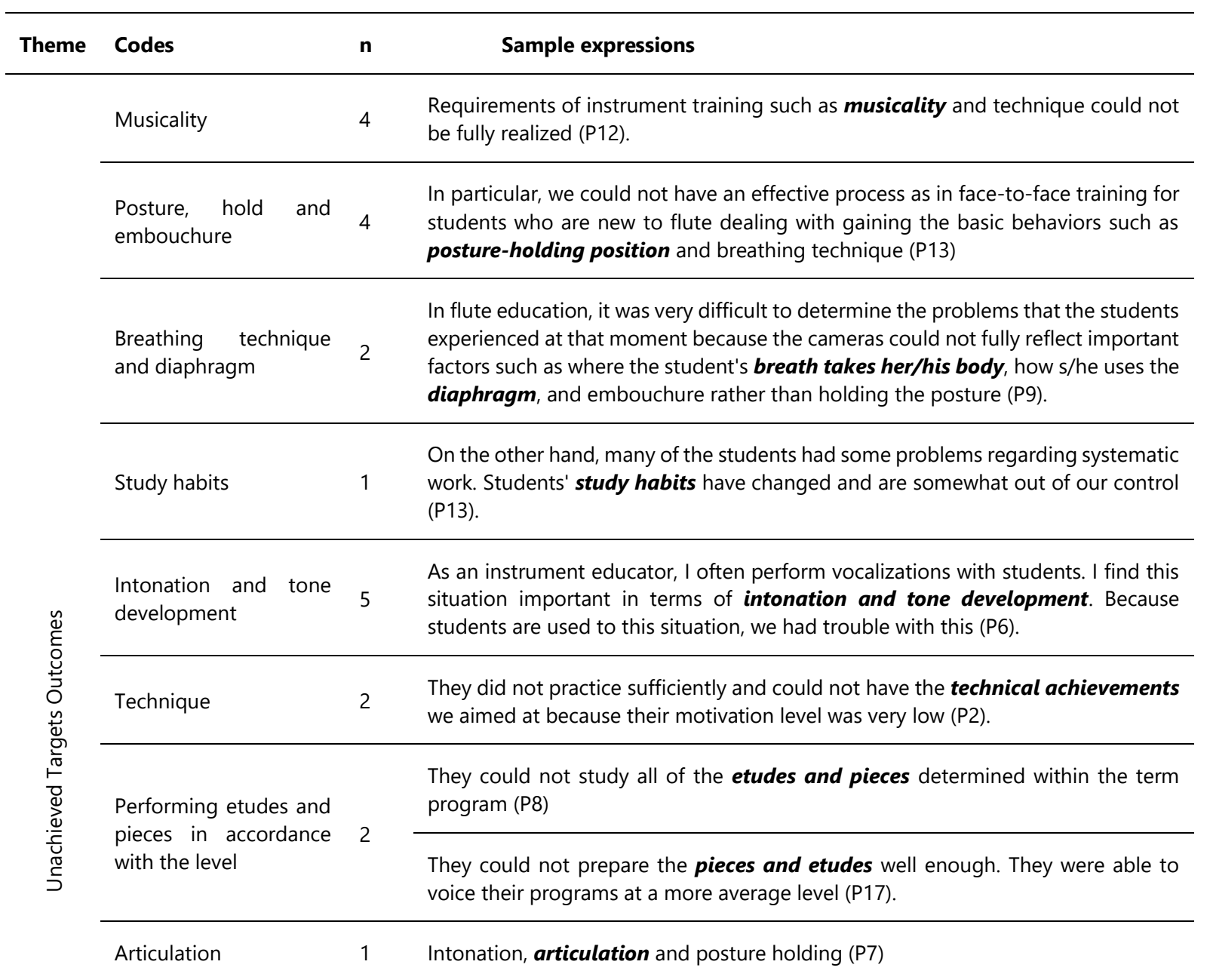

According to Table 10, the flute instructors could not fully achieve their outcomes, particularly the acquisition of intonation and tone development, interpretation/musicality studies, posture/holding and embouchure, breathing technique/diaphragm, technique, etude and piece performance, and articulation at the evel they targeted during the online education process. In addition, flute instructors stated that they could not achieve the above-mentioned outcomes in line with their targets in the 20202021 fall semester, and one of the instructors gave the following answer:

At the end of each academic year, I would organize concert events to stage the realization of our goals. Since it was not possible to hold concerts during this period, I feel the lack of this too much. In particular, the motivation of some of our successful students may decrease in this sense. Synchronous classes are much more interactive than asynchronous ones, but still, face-to-face education cannot be substituted due to our application-based course content (K13). 


\subsection{Competence of Flute Instructors to Teach Online During the COVID-19 Pandemic}

Flute instructors were asked: "If you provided online training during this period, did you find it sufficient? If your answer is 'no', what were the shortcomings you perceived?". The answers given by the participants to the question are shown in Table 11.

Table 11. Flute instructors' views on their own online teaching competencies

\begin{tabular}{|c|c|c|c|}
\hline Theme & Codes & $\mathbf{n}$ & Sample expressions \\
\hline \multirow{4}{*}{ 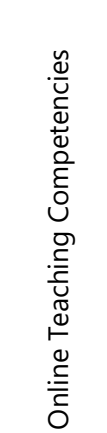 } & Yes & 16 & \\
\hline & $\begin{array}{l}\text { Difficulty } \\
\text { musicality }\end{array}$ & 1 & $\begin{array}{l}\text { I was comfortable in terms of technical training, but it was incredibly difficult } \\
\text { to run musicalty (P10) }\end{array}$ \\
\hline & $\begin{array}{l}\text { Finding insufficient online } \\
\text { course opportunities }\end{array}$ & 4 & $\begin{array}{l}\text { I think I have done my best as an educator, but I think we need more } \\
\text { advanced recording and technological systems other than internet and } \\
\text { computer environment iln terms of playing together, tone development and } \\
\text { musicality (P21) }\end{array}$ \\
\hline & System shortcomings & 1 & There are deficiencies in the system, not me (P16). \\
\hline
\end{tabular}

When Table 11 is examined, it is seen that most of the instructors participating in the study find their competence sufficient to provide online training. In addition to this, one instructor stated that he had difficulty and felt a lack of musicality in the works, while other participants stated that the online course opportunities or the system were inadequate rather than their own competence.

In addition, the instructors were asked whether they had any preparations to improve online flute training, especially during the summer period and beyond. The answers obtained from the interviews are included in Table 12.

Table 12. Preparations of flute instructors for online education

\begin{tabular}{lc}
\hline Preparations & $\mathbf{n}$ \\
\hline No & 3 \\
I researched online lecturing processes & 8 \\
I read publications on the subject & 5 \\
I attended courses / seminars / trainings related to the subject & 14 \\
I corrected my required hardware shortcomings & 12 \\
I learned the use of new programs & 5 \\
\hline
\end{tabular}

When Table 12 is examined, 14 instructors who participated in the study completed the lack of necessary equipment to conduct more efficient online training, 12 instructors learned to use new programs, eight instructors researched online lecturing processes, five instructors read publications on the subject, and five instructors attended courses / seminars / trainings on the subject. In addition, three trainers stated that they did not make any different preparations. Some of the participants' views on the subject are given below. 
"During the summer, we used the trial version of the application called Smart Music developed in America. My students have tried the way to play with pre-recorded substructures with popular music and orchestra arrangements" (P21).

"I attended the Online Programs Education and Material Development course opened by our university" (P8).

"I conducted an extensive literature review on remote instrument training" (P18).

\subsection{Positive Experiences of Flute Instructors in the COVID-19 Process}

In the study, flute instructors were asked to talk about the positive events they experienced in this process or the situations they could see as gains. Instructors generally stated their experiences in terms of professional development and student development. The themes and codes formed from the answers given by the participants to the question are shown in Table 13.

Table 13. Positive experiences of flute instructors in the COVID-19 process

\begin{tabular}{|c|c|c|c|}
\hline Theme & Codes & $\mathbf{n}$ & Sample expressions \\
\hline & & & $\begin{array}{l}\text { In this process, we had the opportunity to reach many people at the same time as technology } \\
\text { was more integrated into education. It was nice to be able to share information with many of } \\
\text { my students at the same time, to create collaborative programs, and to set goals together. In } \\
\text { face-to-face training, I would usually do this individually and it wouldn't be as interactive. } \\
\text { Apart from that, we were able to make music thanks to some programs used for making } \\
\text { music together in digital environment. I think the most positive aspect of this process is to } \\
\text { see that technology and music are sustainable together (P13). }\end{array}$ \\
\hline
\end{tabular}

I was a jury member in an international flute competition online, I made postgraduate thesis defenses online (P10).

Professional development
We learned to use technology more closely, we learned new programs (P2)

We learned to use new programs, and we benefited from voice recording, mixing and editing technologies with my students (P15).

Ötis group, the projects I have participated and done for my school (P1)

The attendance of my students in this semester was quite high. Their determination as an educator motivated me. In the following period, I can say that I will apply synchronous and asynchronous classes, assessment and feedback system during the course in addition to faceto-face training. It is possible to evaluate this period as an achievement in this sense (P21).

We held online concerts on social media, I prepared my students online for the international flute competition and recorded a CD (P10).

Setting goals from the start has been good both for students and me. I allowed them to perform enjoyable duets with themselves in classes that required polyphonic performance

Student development 12 such as chamber music. We learned new things using new apps. The result was good (P17).

The fact that some students make an effort in the flute training process despite all these difficulties and that they were not absent from classes just like face-to-face education shows their labor and efforts. I find this situation positive (P6)

Students' learning in the comfort of their own environment was also a source of motivation for them (20). 
It has been a very rewarding experience to teach a student who has never played flute before, to learn to play from scratch without doing any class face-to-face and managing to improve her/his level (P7)

We did practices with accompaniment, for the first time, we downloaded midi accompaniments on the "flutetunes" website. It was improving for students (P19).

Other

We saved time in terms of working (P2)

Being able to record classes was the only positive side (P12).

Among the participants, there are flute instructors who talk about different experiences and positive examples, as well as instructors who did not give their opinions or answered as "There is no positive example I can give".

\subsection{Suggestions of the Flute Instructors}

In this process, flute instructors were asked about their program and application suggestions as well as their suggestions to other instructors. The themes and codes created through the answers given by the participants are shown in Table 14 .

Table 14. Suggestions of the flute instructors

\begin{tabular}{|c|c|c|c|c|}
\hline Theme & $\begin{array}{l}\text { Sub } \\
\text { theme }\end{array}$ & Codes & $\mathbf{n}$ & Sample expressions \\
\hline & & Quick feedback & 1 & $\begin{array}{l}\text { They should provide fast and qualified feedback on students' performances } \\
\text { as quickly as possible (P13) }\end{array}$ \\
\hline & & \multirow{4}{*}{$\begin{array}{l}\text { Resource } \\
\text { support / } \\
\text { material } \\
\text { creation }\end{array}$} & \multirow{4}{*}{4} & $\begin{array}{l}\text { They should provide support to students in terms of resources and audio- } \\
\text { visual materials }(\mathrm{P} 13) \text {. }\end{array}$ \\
\hline & & & & $\begin{array}{l}\text { An mp3 accompaniment archive can be created so that students can play } \\
\text { their pieces with accompaniment (P15). }\end{array}$ \\
\hline & & & & $\begin{array}{l}\text { Making videos on the subjects that students have difficulties with and } \\
\text { ensuring that students can reach them whenever they need (P4). }\end{array}$ \\
\hline & & & & $\begin{array}{l}\text { Internet-based visual and audio sources should be used more because of } \\
\text { connection and sync problems (P22) }\end{array}$ \\
\hline & & $\begin{array}{l}\text { Being a role } \\
\text { model }\end{array}$ & 1 & $\begin{array}{l}\text { They should introduce their own recordings, videos and artists who can be role } \\
\text { models for them, and enable students to interact with these people (P21). }\end{array}$ \\
\hline & \multirow{5}{*}{ 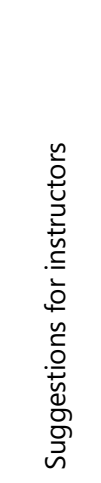 } & Communication & 2 & $\begin{array}{l}\text { Motivation must be provided by staying in constant communication with the } \\
\text { students, otherwise their motivation will constantly decrease (P5) }\end{array}$ \\
\hline \multirow{4}{*}{ 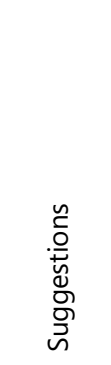 } & & & & I recommend that they interact with the students as much as possible (P18) \\
\hline & & \multirow{2}{*}{$\begin{array}{l}\text { Development in } \\
\text { terms of online } \\
\text { education }\end{array}$} & \multirow{2}{*}{2} & $\begin{array}{l}\text { I recommend that they develop themselves in terms of distance education } \\
\text { philosophy and pedagogy (P18) }\end{array}$ \\
\hline & & & & They should receive training for online education (P7) \\
\hline & & $\begin{array}{l}\text { Technical } \\
\text { infrastructure / }\end{array}$ & 5 & $\begin{array}{l}\text { They can also ensure that the technical equipment used is of good quality } \\
\text { (P18) }\end{array}$ \\
\hline
\end{tabular}


Quality equipment

The programs used should be improved in terms of sound and image quality (P6)

The most important point in this process is technical equipment and knowledge. It is very important to use a good connection program first as our classes are generally application-oriented (P8).

Better sound system, camera system and internet speed (P9).

Technological equipment should be improved (P7).

Students are offered seminars, masterclasses, etc. on online platforms. Supporting their participation, organizing online concerts and motivating students with their participation (P11)

Student referrals 3 They should save children from monotonous education and direct them to online activities like an online concert, masterclass or competition (P10).

Pre-establishing goals and things to work with and set target time to complete (P17)

\begin{tabular}{|c|c|c|}
\hline $\begin{array}{l}\text { Communication } \\
\text { with other } \\
\text { instructors }\end{array}$ & & $\begin{array}{l}\text { meeting can be arranged with lecturers from other faculties about how } \\
\text { ey go through this process. Going to a common program and sharing } \\
\text { xperiences ( } \mathrm{P} 19) \text {. }\end{array}$ \\
\hline
\end{tabular}
instructors experiences (P19).

It should be applied face-to-face, at least partially. Education should be shifted

Face-to-face education

2 to the summer semester (P12)

Face-to-face education should be started (P16)

They should ask students for video assignments (P2)

Homework

2

They can enable them to read more on theoretical subjects such as the historical development of the flute (P21)

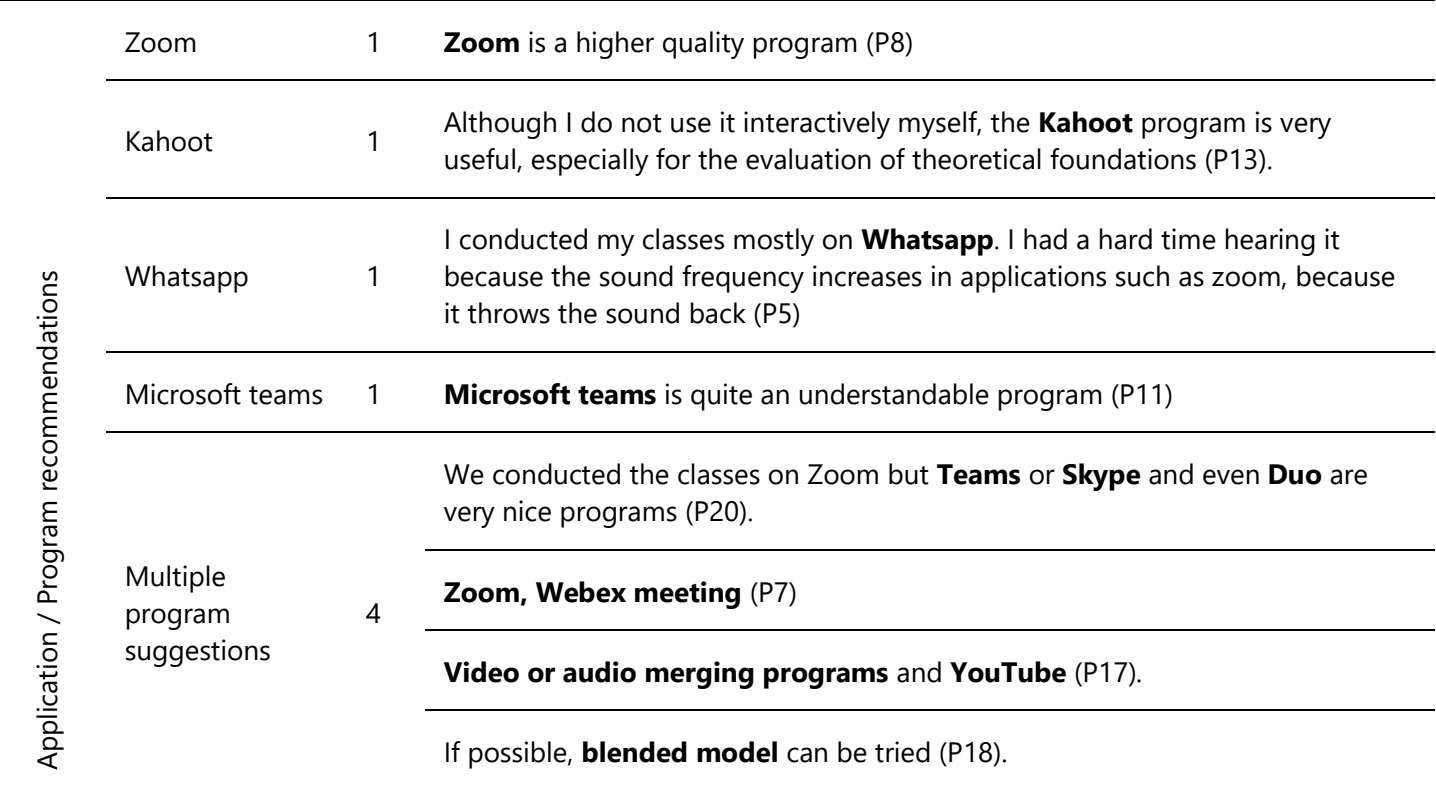




\section{Discussion}

The opinions of the flute instructors in Turkey in the COVID-19 pandemic process were studied using an open-ended and closeended questionnaire. The positive and negative aspects the opinions were analyzed. Accordingly, it was determined that most of the flute instructors in Turkey lacked experience in delivering online classes in the pre-pandemic period. In addition, it is among the findings that four instructors taught online before this process. While two instructors with previous teaching experience stated that they were delivering classes via video calling over different applications, one instructor just said that s/he taught online. Besides, one instructor stated that she applied the flipped learning method, one of the blended learning methods, and this method was also liked by her/his students. A similar conclusion was reached in the study of Aksoy, Güçlü, and Nayir (2020) on distance education situations during the pandemic process of private music courses. In that study, the majority of the participants (91.4 \%) stated that they did not provide instrument training with distance education before the pandemic process.

After the COVID-19 outbreak in Turkey and the class interruption for a short time immediately in all educational institutions, on March 23, 2020, the classes resumed with the distance education method. Education was continued through distance learning over the internet using information technologies (Umuzdaş \& Baş, 2020, p. 206). In this process, plans were made by the Ministry of National Education, Council of Higher Education, and university rectors. With the continuation of distance education with internet facilities in institutions, online education started to be implemented. During this period (March-June 2020), it was determined in the current study that most of the flute instructors did online synchronous or hybrid classes, also, some instructors tried to continue their education with online asynchronous applications, and one instructor attended face-to-face classes. In the 2020-2021 fall semester, it was seen that most of the flute instructors supported synchronous classes with hybrid classes, there were only two instructors who conducted asynchronous classes, and two instructors taught face-to-face.

There is a prevalent opinion among both musicians and instructors that online education alone is not enough (Kesendere, Sakin \& Acar, 2020; Akyürek, 2020). For example, Yizhar Dagan shared the following thoughts in personal interviews: "Teaching musical instruments online is like teaching swimming with clothes \& shoes on" and "teaching musical instruments online is like teaching haute cuisine to someone who has anosmia (smell blindness)" (Dagan, 2021). In the article she wrote in Andante magazine, an important music magazine, Ani Arsu described the changes that had to be experienced and the perspective that had to transform: "The disaster of the century turned the epidemic, possible and impossible, the approved and the objected, turned upside down and the opposite. Many habits that we could not let go of began to be replaced by other habits that were just the opposite. The principles we thought we would never compromise, the strict terms and conditions we set for ourselves, began to change one by one with the guidance of obligations.... online music education is like watching a concert on TV, but not having it means sailing into a dark void" (Arsu, 2021a).

Considering how dangerous the COVID-19 epidemic is in terms of health and how much the risk of contamination by playing an instrument without a mask and blowing is considered, it is appropriate to conduct flute training online within the scope of the measures taken. In this process, the flute instructors tried to cary out the process in the healthiest and most efficient way both through video calls through different applications and with supplementary videos, lecture notes sharing, as well as face-toface class supplements. This process has been similarly shaped not only in terms of flute classes, but also in instrument training almost all over the world.

In the spring semester of 2019-2020, the Ministry of Education has decided not to hold exams and universities decided to do it online. In line with these decisions, most of the flute instructors individually evaluated the videos sent by the students. While two instructors did synchronous or asynchronous commission assessment, four instructors did not hold exams in this 
process. In the next period of the pandemic, although the students were mostly evaluated individually by their instructors, there was an increase in the number of instructors who carried out commission evaluations. There was only one instructor who did not conduct an exam during this period. In this process, it has been a matter of discussion in some universities how instructors can make commission evaluations to provide more effective evaluations, and whether synchronous or asynchronous evaluations can show student performances in the most accurate way. There are institutions that prefer to make video recordings of exams due to the malfunctions in the course processes that are held live (synchronous) (sound loss, internet disconnections, connection problems, etc.). Piano instructor Metin Ülkü, who examines the positive aspects of online instrument training in terms of the student assessment process from a different perspective during the pandemic process, states the following: "The issue of recording the exams I have insisted on before was always rejected for various reasons.... During the epidemic process, exams were recorded and evaluations could be made much more efficiently and healthily" (Arsu, 2021a).

In the music teaching program prepared by the Council of Higher Education, the major instrument training classes appear as theoretical classes for different reasons. For this reason, in addition to the performance exam, written exams with theoretical content were also conducted in some departments of musical education. In the research conducted by Sakarya and Zahal (2020), student views on distance violin education were examined. In that study, half of the students preferred the written exam instead of the performance exam on the grounds that "they will have difficulties in the performance exam in violin education, which could not be done face-to-face." Despite this opinion of the students, it was concluded that flute instructors preferred to conduct performance exams.

In Sakarya and Zahal (2020) study, it was revealed that flute instructors experienced many difficulties during the COVID19 pandemic, including the course process, internet-based technical issues and difficulties, student-induced problems, and instructor-related problems. The flute instructors stated that they had difficulties in the asynchronous class process on the grounds that "feedback cannot be given to students instantly, and the prolongation of the time to give feedback makes some technical problems permanent" (p.13). In addition, the inability to properly control the posture, holding, and position changes that require physical contact in face-to-face classes are among the issues that challenge the instructors in online education. Musical and technical work requires sampling and playing together when appropriate. In online classes, both the applications used in the online courses do not transmit the sound clearly enough and the synchronization problems due to the connection prevent the necessary and effective musicality and technical studies. In addition, these problems caused by the application and internet connection do not allow the student and the instructor to play together.

In addition, the instructors stated that they experienced computer/hardware inadequacies, lack of applications purchased by institutions, as well as internet-related connection problems. Akyürek (2020) reached a similar conclusion in his study and stated that the faculty members had difficulties in the online process due to the problems in internet connections and the problems of voice, frequency, and synchronization as a result of these disruptions. Toros Can talked about similar difficulties and exemplified the situation in terms of the piano. "It is also a problem that programs such as Skype and Zoom are not able to transmit the sound quality enough during online training. When I press a voice or a chord, that voice does not continue on the other side even though I am still pressing it. In this case, it causes serious difficulties in understanding the sentence structure in music" (Arsu, 2021b).

In addition to all these difficulties, the instructors also had difficulties in terms of not being able to find solutions to the problems they had with their students. Akyürek's (2020) study concluded that faculty members have difficulties in online communication with students. 
An instructor, who evaluated this process from a different perspective, stated that listening to videos is much more tiring than listening to a student live, and it is very tiring both for eyes and the mind to constantly study on the computer. In fact, there are also researchers who think that this process is slowed down by methods such as staying at home in line with the measures taken in general and that this will cause fatigue based on the time-space constraint (Karakaş, 2020). While this is true in terms of our daily lives with excessive-performance, overproduction, and excessive communication, it is not true for teachers who spend most of their day face-to-face with their students and need a physical closeness and live communication. In this process, trainers had to spend much more time on the computer, which caused digital fatigue. Meral Yapalı, the retired director and head of the music department of the Istanbul University State Conservatoire, added the same situation to the negative aspects of online courses. "Looking at the screen for a long time and trying to concentrate on the class by hearing the metallic phone sound causes physical fatigue" (Arsu, 2021a).

Other problems faced by flute instructors in this process are students' absenteeism problems, student motivation, lack of instrument/score, the instructor's technological inadequacy, the education of students who have just started musical instrument training, and difficulties related to the environment. "Aim in beginner level instrument education; it is the teaching of the techniques and methods related to the student's instrument and the ability of the student to think musically" (Öz \& Çelenk, 2019). For this purpose, especially in flute education, students are taught to hold the instrument correctly, play with the correct embouchure, blow correctly, play with the correct intonation, etc. It is aimed to achieve the gains. It is very difficult to check the accuracy of these behaviors with the classes seen on the screen. While the posture position can be observed due to the angle of the screen, the lip part remains very small and the embouchure cannot be controlled. Again, it is almost impossible to observe the blowing force and diaphragm movements in front of the screen. In addition, it is not possible to control intonation because internet problems due to poor connection may prevent the sound coming out of the flute from being heard in a correct and clear way. Again, the inability to give immediate feedback to errors made due to synchronization problems caused by connection also creates motivation problems, as it prevents communication. With a similar view, in Ani Arsu's article in Andante magazine, Prof. Toros Can stated that the period in which online education can be most productive is intermediate level and that technical issues can be quite challenging for beginner students in piano with online education opportunities. He also added the following opinion: "At this stage, the student should be able to follow the teacher as a whole and the teacher should intervene to correct errors such as posture when necessary" (Arsu, 2021b).

The flute instructors tried to find different solutions to all these difficulties. The participants have made applications such as keeping the communication strong with students so that the process goes smoothly, recording audio and video for sampling, renewing the score archive as PDF files, requesting the students to make recordings, giving faster feedback, selecting studies and pieces at a simpler level at the beginner level, reinforced with face-to-face classes, purchasing internet packages and strengthening the computers in terms of technical equipment. However, four participants stated that they could not overcome their difficulties.

In that study it was concluded that all these difficulties, trying to overcome or not overcoming these difficulties also affect the achievement of the goals in flute training. The majority of the flute instructors (54.5\%) said that they partially achieved the target outcomes. Besides, the number of participants who answered that they had achieved the targeted gains was seven in the spring semester of 2019-2020 education year and eight in the fall semester of 2020-2021. While three flute instructors answered that they could not achieve the targeted outcomes in the period when the epidemic started, this number decreased to two in the later period of the pandemic. The achievements that are difficult to target and realize are interpretation, musicality, posture, hold and embouchure, breathing technique, and diaphragm studying habit, intonation and tone development, technique, study, and 
articulation appropriate to its level, articulation. As most of the mentioned outcomes are already very difficult to control in the online asynchronous or synchronic class process, it has been mentioned above with the words of different instructors. These opinions support the research.

The flute instructors were asked if they found themselves competent in online education. In line with the findings obtained, it was concluded that most of the instructors (16 participants) found themselves competent. In addition, in parallel with all these difficulties of online flute training, one participant found himself inadequate in training musicality, and five participants stated that they found the online course opportunity or system inadequate rather than themselves.

The participants were asked what they did to improve their skills in this process. While three participants stated that they did not do anything, other participants stated that they researched online lecturing processes, read publications on the subject, attended courses/seminars/trainings related to the subject, corrected the necessary equipment deficiencies, and learned to use new programs. As Saltürk and Güngör (2020, p. 165) also stated in their study, it can be said that "adopting and developing e-learning instead of being skeptical is important in terms of fulfilling the requirements of the current conditions. It seems that both educators and students need to develop additional skills in order to gain efficiency from this educational ecosystem". In this context, it is very important for the instructors to do the necessary research on how to provide more flute training online, to get the necessary training, and especially to meet their hardware needs. However, it is not enough for instructors to improve their skills in this process. As Toros Can stated, "Internet quality / poor quality does not change the intensity of the sound or the clarity of the image, it changes its quality. The variation of the loudness is a big problem on Zoom. While it may be suitable for use in occasions such as chat and meetings but the serious difficulties in transmitting the sound of the piano" (Arsu, 2021b). In this case, it is not enough for the instructor to have a good instrument, a good computer, a speaker, and a microphone. For a productive class, there is a need for applications and programs that have developed synchronization, sound, and image quality to synchronize instrument training online.

Saltürk and Güngör (2020) stated in the recommendations section of their research that there are always prejudiced groups towards distance education. Nevertheless, it is necessary to mention the advantages and the posoitive experiences experienced in this process as well as the negativities and difficulties caused by the pandemic throughout the world. Flute instructors who participated in the study also stated that they had positive experiences in subjects such as professional development, student development, and time planning. Especially, as P13 stated, "seeing that technology and music are sustainable together" will enable teachers to conduct more effective and productive flute classes in this process.

\section{Conclusions and Suggestions}

As a result, even if flute instructors prefer to teach face-to-face and want to switch to face-to-face training as soon as possible, they have made their best efforts in the distance education process. In this process, instructors, who have experienced many internet-related problems, also implemented different applications to compensate for the gains they could not achieve due to this. In this process, the flute instructors have improved their skills related to practices and training methods that they had not experienced before the Covid-19 epidemic process. It is thought that the suggestions developed by the flute instructors in line with their experiences will make the flute training more effective during the Covid-19 pandemic. With this thought in the study, the flute instructors were asked for their suggestions to make this process more efficient in terms of flute training. The suggestions of the participants to the trainers can be summarized as follows:

- Provide quick feedback to students, 
- Provide students with resource support and creating online resources,

- Be a role model,

- Strengthen communication with students,

- Continue professional development in online education,

- Strengthen the technical substructure with quality equipment,

- Encourage students to attend online concerts, masterclasses and seminars,

- Establish communication with other trainers,

- Take the necessary precautions and provide face-to-face course reinforcements.

Participants in the study stated that they used programs such as Zoom, Kahoot, Whatsapp, Microsoft Team, Skype, Duo, Webex meeting, video and audio merging. In addition, suggestions were made for the use of blended programs, if possible.

In addition to the suggestions of the participants, the following suggestions are in line with the findings obtained from the research:

- Participation of flute instructors in training and seminars will contribute to their professional development in terms of teaching online.

- It is necessary to prepare a platform where experiences can be shared in order to be more active in communication with other instrument trainers, especially with flute instructors.

- Applications and programs for online instrument training should be designed,

- Investigation of flute education in terms of students during the COVID-19 pandemic process is needed.

- Creating an online library with piano accompaniment, orchestra accompaniment or flute duets will allow students to work together and share these materials as much as possible. 


\section{References}

Aksoy, Y., Güçlü, O. \& Nayir, A.E. (2020). Distance education status of private music courses during the pandemic process. Millî Eğitim, 49(1), 947-967. https://doi.org/10.37669/milliegitim.827709

Akyürek, R. (2020). The views of lecturers about distance music education process in the pandemıc period. International Journal of Education Technology and Scientific Researches, 5(13), 1790-1833.

Arsu, A. (2021a, January). Uzaktan müzik eğitimi olur mu? - I. Andante, 18(171). Retrieved February 19, 2021 from https://www.idealonline.com.tr/IdealOnline/lookAtPublications/documentIngredient.xhtml?uld=15369\&ioM=Journallss ue

Arsu, A. (2021b, February). Uzaktan müzik eğitimi olur mu? - I. Andante, 18(172). Retrieved February 19, 2021 from https://www.idealonline.com.tr/IdealOnline/lookAtPublications/documentIngredient.xhtml?uld=15720\&ioM=Journallss ue

Baraté, A., Haus, G., \& Ludovico, L.A. (2020). Learning, teaching, and making music together in the COVID-19 era through IEEE 1599. 2020 International Conference on Software, Telecommunications and Computer Networks (SoftCOM). 17-19 September. Hvar, Croatia. Retrieved January 25, 2021 from https://ieeexplore.ieee.org/stamp/stamp.jsp?tp=\&arnumber=9238238

Başkale, H. (2016). Determination of validity, reliability and sample size in qualitative studies. Dokuz Eylül Üniversitesi Hemşirelik Fakültesi Elektronik Dergisi, 9(1), 23-28.

Bolat, M. \& Akıncı, M.Ş. (2020a). Views of university instructors in the field of music about COVID-19 processes, II. Uluslararasi 29 Ekim Bilimsel Araştirmalar Sempozyumu, October 29-31, 2020, Ankara. Retrieved January 25, 2021 from https://www.researchgate.net/publication/347911662_Muzik_Alanindaki_Ogretim_Elemanlarinin_Covid19_Sureclerine_lliskin_Gorusleri

Bolat, M. \& Akıncı, M.Ş. (2020b). Views of undergraduate students in music education about COVID-19 restriction processes, II. Uluslararasi 29 Ekim Bilimsel Araştirmalar Sempozyumu, October 29-31, 2020, Ankara. Retrieved January 25, 2021 from https://www.researchgate.net/profile/Mehmet-Sahin-Akinci/

Budak, F. \& Korkmaz, Ş. (2020). An overall evaluatıon for the COVID-19 pandemıc process: the case of Turkey. Journal of Social Research and Management, 1, 62-79. https://doi.org/10.35375/sayod.738657

Büyüköztürk, Ş., Kılıç Çakmak, E., Akgün, Ö.E., Karadeniz, Ş. \& Demirel, F. (2014). Bilimsel araştırma yöntemleri [Scientific Research Methods]. (18th ed.). Ankara: Pegem Akademi.

Creswell, J.W. \& Plano Clark, V.L. (2020). Karma yöntem araştırmaları tasarımı ve yürütülmesi, Anı Yayınclık [Designing and Conducting Mixed Methods Rresearch]. (Translation Ed. Yüksel Dede, Selçuk Beşir Demir).

de Bruin, L.R. (2021). Instrumental music educators in a COVID landscape: A reassertion of relationality and connection in teaching practice. Fronteers of Psychology, 11(624717). https://doi.org/10.3389/fpsyg.2020.624717.

Dagan, Y. (2021, March 1). Personal interview from Messenger.

Hash, P.M. (2021). Remote learning in school bands during the COVID-19 shutdown. Journal of Research in Music Education, 68(4), 381-397. https://doi.org/10.1177/0022429420967008 
He, Y. (2020). Research on online teaching of music performance based on diversification and intelligence. 2020 International Conference on E-Commerce and Internet Technology (ECIT), pp. 193-196. April 22-24. Zhangjiajie, China. Retrieved January 25, 2021 from https://ieeexplore.ieee.org/stamp/stamp.jsp?tp=\&arnumber=9134197

Johnson, C. \& Merrick, B. (2020). Enabling music students' well-being through regular Zoom cohort chats during the COVID-19 crises. In R.E. Ferdig, E. Baumgartner, R. Hartshorne, R. Kaplan-Rakowski, \& C. Mouza (Eds.). Teaching, Technology, and Teacher Education During the COVID-19 Oandemic: Stories from the Field (pp. 261-264). Waynesvile: Association for the Advancement of Computing in Education (AACE). Retrieved February 25, 2021 from https://www.researchgate.net/publication/342491857_Enabling_Music_Students'_WellBeing_through_Regular_Zoom_Cohort_Chats_During_the_Covid-19_Crises

Karakaş, M. (2020). The multi-sociological aspects of the COVID-19 pandemic and the new normal. ístanbul Üniversitesi Sosyoloji Dergisi, 40, 541-573. https://doi.org/10.26650/SJ.2020.40.1.0048.

Kesendere, Y., Şenol Sakin, A. \& Acar, A.K. (2020). Educators' views on online/distance violin education at COVID-19 outbreak term. Journal for the Interdisciplinary Art and Education, 1(1). 1-19.

National Association for Music Education (NAfME). (2021). State COVID-19 Music Education School Guidance. Retrieved February 16, 2021 from https://nafme.org/covid-19-music-education-school-guidance-documents

Nichols, B.E. (2020). Equity in music education access to learning during the pandemic and beyond. Music Educators Journal, 107(1), 68-70. https://doi.org/10.1177/002743212094515

Öz, B. \& Çelenk, K. (2019). A study on beginner level bassoon training. Atatürk Üniversitesi Sosyal Bilimler Enstitüsü Dergisi, 23(3), 919-936.

Özer, B. \& Üstün, E. (2020). Evaluation of students' views on the COVID-19 distance education process in music departments of fine arts faculties. Asian Journal of Education and Training, 6(3), 556-568. https://doi.org/10.20448/journal.522.2020.63.556.568.

Republic of Turkey Ministry of Health. (2021). Coronavirus Table. Retrieved February 12, 2021 from https://covid19.saglik.gov.tr/EN-69532/general-coronavirus-table.html

Sakarya, G. \& Zahal O. (2020). The student opinions on distant violin education during COVID-19 epidemic. Turkish Studies, 15(6), 795-817. https://dx.doi.org/10.7827/TurkishStudies.44504

Saltürk, A. \& Güngör, C. (2020). Distance education experience of university students during the COVID-19 pandemic. Adiyaman Üniversitesi Sosyal Bilimler Enstitüsü Dergisi, 13(36), 137-174. https://doi.org/10.14520/adyusbd.788716.

Umuzdaş, S. \& Baş, A.H. (2020). Examining the perceptions and experiences of conservatory students regarding distance education during the COVID-19 pandemic. Yegâh Mûsikî Dergisi, 3(2), 204-220.

World Health Organization (WHO) (2020). WHO Director-General's opening remarks at the media briefing on COVID-19 - 11 March 2020. Retrieved February 12, 2021 from https://www.who.int/director-general/speeches/detail/who-directorgeneral-s-opening-remarks-at-the-media-briefing-on-covid-19---11-march-2020 